\title{
ANALISIS HYGIENE SANITASI PEDAGANG ES KELAPA MUDA DENGAN PEMERIKSAAN KANDUNGAN BAKTERI E.COLI DI KECAMATAN BANJARBARU UTARA
}

\section{Analysis Hygiene Sanitation Traders Young Coconut Ice to The Inspection of The Wom Bacteria E.Coli in District Banjarbaru Utara}

Hilda Irianty, Mahmudah, Norsita Agustina

Universitas Islam Kalimantan MAB Banjarmasin

(hildanafarin@gmail.com, 085251150724)

\begin{abstract}
ABSTRAK
Makanan dan minuman sangat penting bagi manusia karena merupakan salah satu kebutuhan pokok untuk kelangsungan hidupnya dan di dalam makanan dan minuman tersebut terkandung senyawa. Tujuan penelitian mengetahui kandungan bakteri E.Coli pada minuman es kelapa muda di Kecamatan Banjarbaru Utara. Menggunakan pendekatan kualitatif dengan metode studi kasus pada pedagang es kelapa muda dengan cara pemeriksaan laboratorium terhadap es kelapa muda. Sampel penelitian sebanyak 25 pedagang es kelapa muda yang berada di Kecamatan Banjarbaru Utara.Hasil sebanyak 20 sampel es kelapa muda (80\%) positif mengandung bakteri E.Coli; hanya 5 sampel (20\%) yang negatif bakteri E.Coli.Temuan perilaku kurang higienis dari penjamah/pedagang es kelapa muda antara lain penggunaan air mentah untuk membuat es; tidak menggunakan celemek atau tutup kepala; tidak mencuci tangan terlebih dahulu sebelum pengolahan;serta peralatan yang kurang bersih.Kesimpulan: sebanyak $80 \%$ es kelapa muda di Kecamatan Banjarbaru Utara terkontaminasi bakteri E. Coli. Di sarankan untuk meningkatkan pengawasan dan bimbingan kepada para pedagang es kelapa muda agar menerapkan perilaku hygiene sanitasi dalam pengolahan dan penyajian es kelapa muda.
\end{abstract}

Kata Kunci : Higiene Sanitasi, pedagang es kelapa muda, bakteri e.coli

\section{ABSTRACT}

Food and drink that it is extremely important for the human being because it is one of basic needs for their survival and all that is in in food and those drinks contained a compound to know the content of E.Coli bacteria in young coconut ice drink in North Banjarbaru Subdistrict. Using a qualitative approach with a case study method on a young coconut ice trader by means of laboratory examination of young coconut ice. Samples of research as many as 25 traders of coconut ice in the District of North Banjarbaru. as many as 20 samples of young coconut ice (80\%) positive contain E. coli bacteria; only 5 samples (20\%) were negative E. coli bacteria. The findings of less hygienic behavior of young coconut ice traders / traders include the use of raw water to make ice; not using aprons or headgear; not washing hands first before processing; and less clean equipment. as much as $80 \%$ of young coconut ice in North Banjarbaru District contaminated with E. Coli bacteria. improve supervision and guidance to young coconut ice traders to apply hygiene sanitation practices in processing and serving young coconut ice.

Keywords: Higiene sanitation,traders oung coconut ice,e.coli bacteria 


\section{PENDAHULUAN}

Di Indonesia dan Negara-negara Asia lainnya menggunakan bakteri E. coli untuk pengujian air minum. Bakteri E. Coli lebih mudah mengisolasinya dari pada jenis bakteri lainnya. Keberadaan bakteri E. Coli dalam sumber air atau makanan merupakan indikasi pasti terjadinya kontaminasi tinja manusia. ${ }^{1}$

Pesatnya perkembangan berbagai kebutuhan masyarakat di Kota Banjarbaru, diikuti juga dengan pesatnya perkembangan jajanan di Kota Banjarbaru, khususnya di Kecamatan Banjarbaru Utara.Keberadaan jajanan pinggir jalan ini dapat memberikan lebih banyak variasi aneka jajanan makanan dan minuman yang bisa ditemukan dan dikonsumsi oleh masyarakat secara praktis dengan harga yang relatif murah.Salah satu jajanan pinggir jalan yang banyak ditemukan disekitar Kecamatan Banjarbaru Utara adalah es kelapa muda. Es kelapa muda yang dingin dan segar dapat menghilangkan rasa haus pembeli. Kelapa adalah satu jenis tumbuhan dari suku aren-arenan atau Arecaceae dan adalah anggota tunggal dalam marga Cocos.Tumbuhan ini dimanfaatkan hampir semua bagiannya oleh manusia sehingga dianggap sebagai tumbuhan serba guna, khususnya bagi masyarakat pesisir.Kelapa juga adalah sebutan untuk buah yang dihasilkan tumbuhan ini. Kelapa yang masih muda biasanya memiliki daging buah yang masih lunak dan kandungan air yang banyak dengan rasa yang manis, sehingga oleh masyarakat sering dibuat sebagai minuman yang biasanya ditambahkan es sehingga sering disebut es kelapa muda. $^{2}$

Dari hasil penelitian terdahulu oleh Manalu (2005) tentang Higiene Sanitasi Es Campur yang dijual di Kota Medan tahun 2005, menunjukkan bahwa es campur yang dijual oleh pedagang kaki lima di Pasar Mercu Buana dan Petisah, 2 dari 12 es campur yang dijual telah memenuhi syarat kesehatan. Sedangkan dipasar Sukaramai, pasar Aksara, pasar Pringgan, pasar Sei Sikambing dan pasar Pulo Brayan semua es campur yang dijual oleh pedagang tidak memenuhi syarat kesehatan sebanyak 21,38\% dan $>240$ E. Coli. $^{3}$ Sedangkan penelitian oleh Purba (2013) dari 8 pedagang es kelapa muda di Kelurahan Lauchi, semua pedagang es kelapa muda yang es kelapa mudanya dicampur dan tanpa di campur es hasilnya positif terdapat kandungan bakteri E. Coli. ${ }^{4}$ Tujuan Penelitian untuk mengetahui Hygiene sanitasi pedagang es kelapa muda dan Kandungan bakteri E.Coli pada minuman es kelapa muda di Kecamatan Banjarbaru Utara Tahun 2017.

\section{BAHAN DAN METODE}

Penelitian ini menggunakan pendekatan secara kualitatif dengan metode studi kasus pada kandungan es kelapa muda. Penelitian ini dilaksanakan dari bulan oktoberJanuari 2018 dan peneltian ini dilakukan di wilayah Kecamatan Banjarbaru Utara. Populasi dan Sampel penelitian yang dilakukan sebanyak 25 pedagang es kelapa muda yang ada di wilayah Kecamatan Banjarbaru Utara. 
Data yang digunakan ada dua dalam penelitian ini yaitu data primer dan data sekunder. Data primer diperoleh dari hasil wawancara dari informan dan observasi dilapangan serta ditambah dari hasil kuesioner yang diisi oleh responden. Data sekunder diperoleh dari hasil uji laboraturium tentang kandungan bakteri E.Coli. Analisis data atau informasi dalam penelitian ini melalui 3 tahapan, tahapan pertama melakukan reduksi data atau merangkum data yang diambil dari hal-hal pokok dari penelitian ini seperti hal-hal hygine sanitasi pedagang es kelapa muda dari kebersihan tempat dan pada saat penyajian, kebersihan personal hygiene sampai pada tahap lokasinya berjualan. Tahapan kedua penyajian data, data yang sudah diperoleh secara keseluruhan dijabarkan atau dinarasikan oleh peneliti. Dalam penyajian data tentang hygiene sanitasi pedagang es kelapa muda pada hasil wawancara dan observasi/pengamatan langsung, ada beberapa pedagang yang pada saat penyajian masih tidak cuci tangan terlebih dahulu dan tidak menggunakan celemek. Dari hasil uji laboraturium dari 25 sampel es kelapa muda yang di uji terdapat 23 sampel yang positif mengandung bakteri E.Coli. Melihat tingginya hasil sampel uji laboraturium peneliti menggali lagi informasi asal mula es yang digunakan kepada informan dari informasi informan ada yang meolah sendiri esnya dan ada yang membeli diwarung atau di antar oleh distributor. Peneliti juga menggali informasi kepada pedagang yang hasil uji labnya negatif bakteri E.Coli bahwa es yang digunakan membuat sendiri. Tahapan ketiga menarik kesimpulan setelah semua informasi atau data didapat. Setelah data dikumpulkan semua baru di analisis yaitu dari hasil wawancara,observasi lapangan dan kuesioner. Analisis data dalam penelitian ini dari awal dan akhir penelitian.dimulai dari menggali informasi dari informan saat wawancara dan pengamatan secara langsung sambil mengambil sampel es kelapa muda yang selanjutnya dibawa ke laboraturium untuk mengetahui hasil uji sampelnya.

\section{HASIL}

Dari penelitian ini didapatkan distribusi responden menurut jenis kelamin, sebanyak 15 responden $(56,0 \%)$ berjenis kelamin laki-laki dan sebanyak 10 responden $(44,0 \%)$ berjenis kelamin perempuan. Dan distribusi responden menurut lama berjualan, sebanyak 14 pedagang yang baru berjualan sekitar 1-4 tahun, sedangkan yang sudah sampai 5 tahun berjualan hanya $5(20,0 \%)$ orang pedagang. Dari 25 pedagang es kelapa muda terdapat 6 pedagang yang paling lama berjualan sekitar 6-8 tahun.

Analisis higiene sanitasi dilihat dari prinsip higiene sanitasi yaitu dimulai dari pemilihan bahan baku, penyimpanan bahan baku,pengolahan, penyimpanan bahan jadi, pengangkutan dan yang terakhir penyajian. Berdasarkan hasil penelitian di Kecamatan Banjarbaru Utara, menunjukkan bahwa dari 25 pedagang es kelapa muda sebanyak 23 (92\%) 
pedagang yang bahan baku minuman es kelapanya masih baik,segar dan tidak berbau. Sedangkan dari 25 pedagang terdapat 1(4\%) pedagang yang bahan baku dicampur dengan air mentah. Untuk bahan baku es yang digunakan sebanyak $22(88 \%)$ pedagang yang esnya berasal dari membeli hanya $3(12 \%)$ pedagang yang esnya mengolah sendiri.

Dari hasil penelitian berdasarkan penyimpanan bahan baku, dari 25 pedagang es kelapa muda sebanyak 17 pedagang yang tempat penyimpanan bahan baku tertutup, dan sebanyak 8 pedagang yang tempat penyimpanannya tidak tertutup. Untuk tempat/wadah yang bebas dari debu/lalat terdapat 20 pedagang yang penyimpanannya bebas dari debu/lalat dan 23 pedagang yang tempat penyimpanan bahan baku dalam keadaan bersih. Dilihant dari pengolahan minuman es kelapamuda menunjukkan hasil penelitian dilihat dari higiene penjamah sebanyak 22 pedagang tidak menggunakan celemek/tutup kepala dan 3 pedagang yang tidak menggunakan celemek/tutup kepala. Sedangakan dilihat dari higiene tempat pengolahan minuman dari 25 pedagang es kelapa muda, semua pedagang tidak mencuci peralatan pengolahannya dengan air mengalir dan hanya 18 pedagang yang tempat pengolahannya bebas dari lalat. Dilihat dari higiene cara pengolahan minuman es kelapa muda terdapat 23 pedagang yang tidak mencuci tangan sebelum pengolahan dan 7 pedagang yang bercakap-cakap pada saat pengolahan,sedangkan terdapat 2 pedagang yang batuk atau bersin saat pengolahan minuman.

Hasil penelitian ada sebanyak 21 pedagang es kelapa muda yang minuman es kelapa mudanya disimpan di dalam termos atau wadah yang bersih dan tertutup. Sedangkan sebanyak 5 pedagang yang tidak menyimpan air kelapa muda didalam termos atau wadah dari pagi sampai sore. dilihat dari 25 pedagang es kelapa muda dalam pengangkutan minuman es kelapa muda semua pedagang tidak ada tempat untuk mengangkut minuman yang sudah jadi dan tidak mengakut minuman dalam keadaan tertutup. berdasarkan hasil penelitian dari segi penyajian minuman es kelapa muda, dari 25 pedagang es kelapa muda terdapat 1 pedagang yang peralatan penyajiannya tidak bersih dan peralatan penyajian yang dicuci dengan air mengalir. Sedangkan sebanyak 3 pedagang yang tidak mengeringkan peralatan setelah dicuci, dan sebanyak 21 pedagang yang peralatan penyajiannya bebas dari lalat. Dari 25 sampel yang diambil terdapat 20 sampel yang hasilnya positif mengandung bakteri E. Coli dan 5 sampel yang hasilnya negatif mengandung bakteri E.Coli. sehingga hasilnya tidak memenuhi syarat sesuai dengan Permenkes RI No. 492/Menkes/PER/IV/2010 tentang Persyaratan Kualitas Air Minum yaitu 0 per $100 \mathrm{ml}$ sampel.

\section{PEMBAHASAN}

Pada hasil observasi dilapangan masih ada pedagang yang mencampur bahan baku es 
kelapa muda dengan air mentah padahal sudah pasti penggunaan air mentah akan memicu adanya perkembangan mikroba pada es kelapa muda tersebut. Dari hasil pemeriksaan laboraturium kesehatan pada pedagang yang menggunakan tambahan air mentah sudah pasti hasilnya es kelapa muda tersebut positif mengandung bakteri E.Coli. dan dari hasil observasi apabila pedagang membuat atau mengolah sendiri esnya maka hasil dari laboraturium kesehatan air es kelapa mudanya negatif mengandung bakteri E.Coli. Penelitian ini sejalan dengan penelitian terdahulu oleh Purba, dkk.2013 di Kelurahan Lauchi memiliki higiene sanitasi pengolahan minuman air kelapa muda yang tidak memenuhi syarat sebanyak 8 pedagang, pada pemilihan bahan baku minuman air kelapa muda semua pedagang sudah memenuhi syarat kesehatan dalam memilih bahan baku minuman yang berkualitas, hal ini terlihat dari seluruh responden dapat memilih bahan baku dalam keadaan segar dan tidak busuk, masih baik dan utuh. ${ }^{4}$

Sedangkan penelitian Lubis di taman teladan kecamatan Medan tahun 2012, Bahan baku minuman es kelapa muda adalah kelapa muda, jeruk kasturi, dan gula pasir. ${ }^{5}$ Dari hasil observasi, tidak semua pedagang sudah memenuhi syarat kesehatan dalam memilih bahan baku minuman yang berkualitas mutu yang baik.Hal ini terlihat dari kondisi pemilihan bahan baku dari segi fisik dan terdapat 2 dua pedagang yang terlihat memilih bahan baku kelapa muda yang masih kotor dan jeruk kasturi hampir busuk yaitu pada pedagang dengan kode sampel 1 dan 3. Kelapa muda yang kotor ketika dibelah dan akan diolah, kemungkinan besar akan mengkontaminasi air dan daging kelapa muda tersebut.

Berdasarkan hasil penelitian terdahulu oleh Lubis tahun 2012 di kecamatan Medan Kota dapat dilihat bahwa beberapa pedagang langsung memakai semua bahan minuman sehingga tidak perlu tempat khusus, sedangkan yang menyimpan sebagian bahan minumannya disimpan didalam toples atau plastik..$^{5}$ Toples biasanya digunakan untuk menyimpan gula ataupun air gula, sedangkanplastik untuk menyimpan jeruk kasturi. Tidak semua pedagang memenuhi syarat kesehatan dalam penyimpanan bahan minuman. Dari lima pedagang, tidak ada pedagang yang menyimpan bahan minuman di tempat yang bersih dan kedap air.Sedangkan pada tempat penyimpanan,semua pedagang menyimpan bahan minuman dalam keadaan terbuka. Dalam penyimpanan bahan baku minuman es kelapa muda pedagang belum memenuhi syarat kesehatan. Sebaiknya, pedagang menyimpan bahan baku minuman di tempat yang bersih dan kedap air dan disimpan dalam keadaan tertutup untuk mengurangi kontaminasi terhadap bakteri. Berdasarkan dari hasil penelitian di Kecamatan Banjarbaru Utara, walaupun sudah sebagian pedagang yang menyimpan bahan baku kedalam toples atau wadah yang tertutup, tetapi masih ada beberapa pedagang yang wadah atau toplesnya 
tidak bersih dan tidak bebas dari lalat atau debu.

Penelitian ini sejalan dengan penelitian Purba, dkk tahun 2013 menunjukkan bahwa pengolahan minuman yang dilakukan oleh pedagang tidak mencuci tangan setiap kali hendak menangani minuman, tidak mencuci bahan mentah dengan air matang dan tidak mencuci peralatan pengolahan dengan menggunakan air yang mengalir. ${ }^{4}$ Oleh karena itu pengolah minuman harus selalu dalam keadaan sehat dan terampil serta menerapkan prinsip higiene yang benar saat menangani yang dibuatnya. ${ }^{6}$ Dari hasil observasi langsung memang masih banyak pedagang yang menyimpan air es kelapa muda dalam termos dari pagi sampai sore padahal sangat berisiko mengandung bakteri karena kelamaan dapat memicu bau atau rasa asam pada air kelapa muda tersebut. Dalam penyimpanan makanan dan minuman yang paling perlu diperhatikan adalah suhu dan tempat penyimpanan minuman tersebut. Tempat penyimpanan minuman jadi harus terpisah dengan bahan baku minuman . ${ }^{7}$

Untuk pengangkutan minuman es kelapa muda yang sudah jadi dalam hasil penelitian ini menunjukkan bahwa pengangkutan yang dilakukan pedagang hanya ada 7 pedagang yang mengangkut dengan gerobak dorong tanpa keadaan tertutup sehingga perlu diperhatikan dengan cara peralatan yang akan dipakai pada saat pengolahan dalam keadaan tertutup seperti wadah atau termos untuk menyimpan kelapa muda,untuk menyimpan es batu, dan untuk wadah air gula pasir,sirup dan air gula merah.

Penelitian ini sejalan dengan penelitian Purba, dkk 2013, yang mana hasil penelitiannya menunjukkan bahwa pengangkutan minuman air kelapa muda yang dilakukan pedagang yaitu dengan menggunakan gerobak dorong. ${ }^{4}$ Minuman yang akan diangkut tidak dalam keadaan tertutup, sehingga perlu diperhatikan baik cara dan peralatan yang digunakan untuk mengangkut minuman karena akan terjadi kontaminasi apabila kondisinya tidak baik.

Peralatan penyajian jadi salah satu penting yang sangat berpengaruh terhadap ada atau tidaknya kandungan bakteri E.coli di dalam es kelapa muda. Pada hasil observasi masih banyaknya di temukan peralatan yang digunakan oleh pedagang tidak di cuci dengan air mengalir hanya saja mereka menggunakan air yang di ada di dalam ember untuk mencuci semua peralatan, seperti sendok dan gelas secara berulang-ulang sampai air di dalam ember kelihatan keruh. Dalam proses pengeringan gelas masih ada pedagang setelah dicuci langsung digunakan kembali. Sama halnya dengan pencucian tempat air kelapa mudanya atau tempat es mereka hanya mencuci sedikit dengan air. Pada hasil pemeriksaan uji laboraturium masih ada hasil positif bakteri E.coli yang disebabkan oleh peralatan yang tidak higienes walaupun peralatan pada saat penyajian bebas dari lalat.

Penelitian ini sejalan dengan penelitian yang dilakukan Purba, dkk pada tahun 2013 di 
Kelurahan Lauchi dimana pada hasil penelitiannya keseluruhannya pedagang es kelapa muda hanya menggunakan air 1 kali pemakaian yang ada di ember saja untuk membilasnya dan digunakan secara berulangulang. ${ }^{4}$ Hal ini berarti peralatan yang digunakan tidak terjamin kebersihannya serta pemakaian yang berulang-ulang berisiko untuk menularkan berbagai macam virus dan bakteri yang dapat menular melalui makanan seperti kolera, tifus, disentri, atau tubercolosis sehingga kesehatan konsumen bisa terancam.

Dari hasil pemeriksaan kandungan bakteri E.Coli yang positif disebabkan es yang digunakan berasal dari es yang diambil dari distributor atau membeli di warung. Kemungkinan es yang membeli di warung air yang digunakan tidak di masak yang mengambil langsung dari kran air yang langsung diolah sehingga keberadaan E.coli dalam air memiliki korelasi tinggi ditemukannya penyakit.

Sedangkan hasil yang negatif kandungan bakteri E.Coli pada saat wawancara es yang digunakan berasal dari mengolah sendiri. Selain berasal dari es yang digunakan bisa berasal dari peralatan yang kurang bersih dan tidak cuci tangan, karena pada saat pengambilan sampel ada mengambil air kelapa muda yang menggunakan es dan ada juga yang tidak menggunakan es tetapi hasilnya ada es kelapa muda yang positif mengandung bakteri E.coli.

Penelitian ini sejalan dengan penelitian Purba, dkk, yang mana hasil penelitiannya es kelapa muda yang tanpa es dijumpai kandungan bakteri E.Coli yaitu 716 per $100 \mathrm{ml}$ yang berada dalam kisaran 4,0 sampai 240 per100 $\mathrm{ml}$ sampel sehingga hasilnya tidak memenuhi syarat atau hasilnya positif semua. ${ }^{4}$ Hasil pemeriksaan yang dilakukan pada air kelapa muda ini terjadi karena kontaminasi bakteri E.Coli yang terlihat disebabkan oleh penggunaan bahan campuran air yang tidak dimasak. Ditambah lagi, kondisi kelapa muda saat membuka menggunakan pisau yang tidak bersih, terkontaminasi dengan tangan yang tidak di cuci bersih. Sedangkan dengan menggunakan es hasil pemeriksaan tetap hasilnya positif semua, dapat terjadi karena pedagang menggunakan es kulkas yang tidak air dimasak sehingga keberadaan E.Coli didalam air ditemukan.

Kontaminasi bakteri E.Coli pada air kelapa dengan air kelapa dengan campuran es terlihat dari penggunaan air pencampuran yang tidak sempurna dan tidak dimasak $100^{\circ} \mathrm{C}$ yang berisiko menjadi tempat perkembangbiakan bakteri tersebut. Selain itu ada juga ada dari penelitian Lubis (2012), menyatakan bahwa air kelapa muda yang dicampur es batu diperiksa mengandung E.Coli sehingga tidak memenuhi syarat kesehatan. ${ }^{5}$ Hal ini berarti bahwa air kelapa muda yang dicampur es batu disebabkan oleh pedagang yang tidak mencuci termos penyimpanan es terlebih dahulu sebelum es dimasukkan, dan pedagang tidak mencuci sendok pengambil es sebelum digunakan. 


\section{KESIMPULAN DAN SARAN}

Terdapat 20 sampel $(80 \%)$ es kelapa muda yang positif mengandung/terkontaminasi bakteri E.Coli dan 5 sampel yang negatif mengandung bakteri E.Coli. Masih banyak ditemukan pedagang yang tidak menggunakan celemek atau tutup kepala pada saat penyajian dan hampir semua pedagang yang tidak mencuci tangan terlebih dahulu pada saat pengolahan minuman es kelapa muda sehingga memungkinkan terjadinya kontaminasi bakteri E. Coli. Hal lainnya yang diduga menjadi penyebab terjadinya kontaminasi bakteri E.Coli pada es kelapa muda antara lain penggunaan air mentah yang digunakan untuk membuat es, dan perilaku dan peralatan yang kurang higienis dari penjamah minuman es kelapa muda. Dinas Kesehatan agar memberikan bimbingan dan pengetahuan kepada pedagang es kelapa muda tentang higine sanitasi terhadap pengolahan minuman es kelapa muda. Balai Pengawasan Obat dan

\section{DAFTAR PUSTAKA}

1. Chandra B. Pengantar Kesehatan Lingkungan. Jakarta: Penerbit Erlangga; 2007.

2. Muzafri, Al. Deteksi Kehadiran Mikroba Indikator di Dalam Es Kelapa Muda di Kecamatan Tampan, Kota Pekanbaru. [Serial Online]. 2013. [Diakses 14 Juli 2017].

(http://repository.unri.ac.id/xmlui/bitstream/ handle/123456789/3013/REPOSITORI\%20 AL\%20MUZAFRI.pdf?s).
Makanan agar diadakannya pengawasan terhadap pedagang es kelapa muda 2 kali dalam setahuan. Pedagang es kelapa muda hendaknya menerapkan higine sanitasidalam mengolah es kelapa muda dan melayani pelanggan sehingga es kelapa yang dijual dapat memenuhi syarat kesehatan dan terbebas dari bakteri E.Coli. Bagi Peneliti Selanjutnya disarankan agar untuk memperdalam lagi penelitian ini dengan menambahkan beberapa Variabel atau diubah menjadi penelitian kuantitatif.

\section{UCAPAN TERIMA KASIH}

Ucapan terima kasih disampaikan kepada kampus Uniska MAB Banjarmasin yang telah mendanai penelitian ini, yang kedua ke Kecamatan Banjarbaru Utara yang telah memberikan izin penelitian di Wilayah Banjarbaru Utara, dan yang ketiga kepada teman-teman Tim Peneliti yang telah membuat penelitian ini.

3. Manao. Higiene Sanitasi Pengelolaan dan Pemeriksaan Kandungan Escherichia Coli Dalam Mie Gomak yang Dijual Di Pasar Sidikalang. [Serial Online]. 2012. [Diakses 15 Juli 2017].

(http://www.academia.edu/19590029/HIGI ENE_SANITASI_PENGELOLAAN

DAN_PEMERIKSAANKANDUNGAN_E SCHERICHIA_COLI_DALAM_MIE_GO MAK_YANG_DIJUAL_DI_PASAR_SIDI KALANG_TAHUN_2012). 
4. Purba, Kezia Ramayana BR, dkk. Analisis Higiene Sanitasi Pengolahan dan Pemeriksaanbakteri E. Coli Pada Minuman Air Kelapa Muda yang Dijual Dikelurahan Lauchi Kecamatan Medan Tuntungan Medan Tahun 2013. [Serial Online]. 2013. [Diakses $14 \quad$ Juli 2017$]$ (https://media.neliti.com/media/publication s/14511-ID-analisis-higiene-sanitasipengolahan-dan-pemeriksaan-bakteri-ecoli-pada-minuman.pdf.)

5. Lubis, Anggrainy. Higiene Sanitasi dan Analisa Eschericia coli pada Minuman Es Kelapa Muda yang Dijual Di Taman Teladan Kecamatan Medan Kota Tahun
2012. [Serial Online] 2012. [Diakses 17 Juli 2017]

(http://repository.usu.ac.id/handle/1234567 89/34098)

6. Purawidjaja. Enam Prinsip Dasar Penyediaan Makanan di Hotel, Resoran dan Jasaboga. [Serial Online]. 1995. [Diakses tanggal 14 Juli 2017] (http://www.putraprabu.wordpress.com/200 9/01/09 /penyajian-makanan-prinsip-foodhigiene/)

7. Purnawijayanti, H. Sanitasi Higiene dan Keselamatan Kerja dalam Pengelolaan Makanan. Yogyakarta: Penerbit Kanisius; 1999. 


\section{LAMPIRAN}

1. Distribusi Responden Menurut Jenis Kelamin

Tabel 1.

Distribusi Responden Berdasarkan Jenis Kelamin Pedagang Es Kelapa Muda Di Kecamatan Banjarbaru Utara

\begin{tabular}{lcc}
\hline \multicolumn{1}{c}{ Jenis Kelamin } & f & \% \\
\hline Laki-laki & 15 & 60,0 \\
Perempuan & 10 & 40,0 \\
Jumlah & 25 & 100 \\
\hline
\end{tabular}

Sumber : Data Primer, 2017

\section{Distribusi Responden Menurut Lama Berjualan}

Tabel 2.

Distribusi Responden Berdasarkan Lama Berjualan Es Kelapa Muda Di Kecamatan Banjarbaru Utara

\begin{tabular}{lcc}
\hline Lama Berjualan & f & \% \\
\hline 1- 4 Tahun & 14 & 56,0 \\
5 Tahun & 5 & 20,0 \\
6-8 Tahun & 6 & 24,0 \\
Jumlah & 25 & 100 \\
\hline
\end{tabular}

Sumber : Data Primer, 2017

\section{Pemilihan Bahan Baku}

Tabel 3.

Distribusi Responden Berdasarkan Pemilihan Bahan Baku Minuman Es Kelapa Muda Di Kecamatan Banjarbaru Utara

\begin{tabular}{lllll}
\hline Kriteria Penilaian & Ya & \multicolumn{3}{c}{ Tidak } \\
\cline { 2 - 6 } & $\mathbf{n}$ & $\mathbf{\%}$ & $\mathbf{n}$ & $\mathbf{\%}$ \\
Bahan minuman terlihat masih & 23 & 92,0 & 2 & 8,0 \\
baik, segar dan tidak berbau & & & & \\
Bahan baku minuman & 0 & 0 & 25 & 100 \\
dicampur dengan bahan baku & & & & \\
yang kemaren & & & & \\
$\begin{array}{l}\text { Bahan baku minuman } \\
\text { dicampur dengan air mentah }\end{array}$ & 4,0 & 24 & 96,0 \\
$\begin{array}{l}\text { Bahan baku es yang } \\
\text { digunakan berasal dari } \\
\text { membeli, bila tidak es yang }\end{array}$ & 88,0 & 3 & 12,0 \\
digunakan mengolah sendiri
\end{tabular}

Sumber : Data Primer, 2017 


\section{Penyimpanan Bahan Baku Minuman Es Kelapa Muda}

Tabel 4.

Distribusi Responden Berdasarkan Penyimpanan Bahan Baku Minuman Es Kelapa Muda Di Kecamatan Banjarbaru Utara Kriteria Penilaian Ya Tidak

Tempat/wadah

\begin{tabular}{llll}
\hline $\mathbf{n}$ & \% & $\mathbf{n}$ & \% \\
\hline 17 & 68,0 & 8 & 32,0
\end{tabular}

penyimpanan

bahan baku tertutup

$\begin{array}{lllll}\text { Tempat/wadah } & 20 & 80,0 & 5 & 20,0\end{array}$

penyimpanan bebas

dari debu/lalat

$\begin{array}{lllll}\text { Tempat } & 23 & 92,0 & 2 & 8,0\end{array}$

penyimpanan

bahan baku dalam

keadaan bersih

Sumber : Data Primer, 2017

\section{Pengolahan Minuman Es Kelapa Muda}

Tabel 5.

Distribusi Responden Berdasarkan Pengolahan

Minuman Es Kelapa Muda Di Kecamatan Banjarbaru Utara

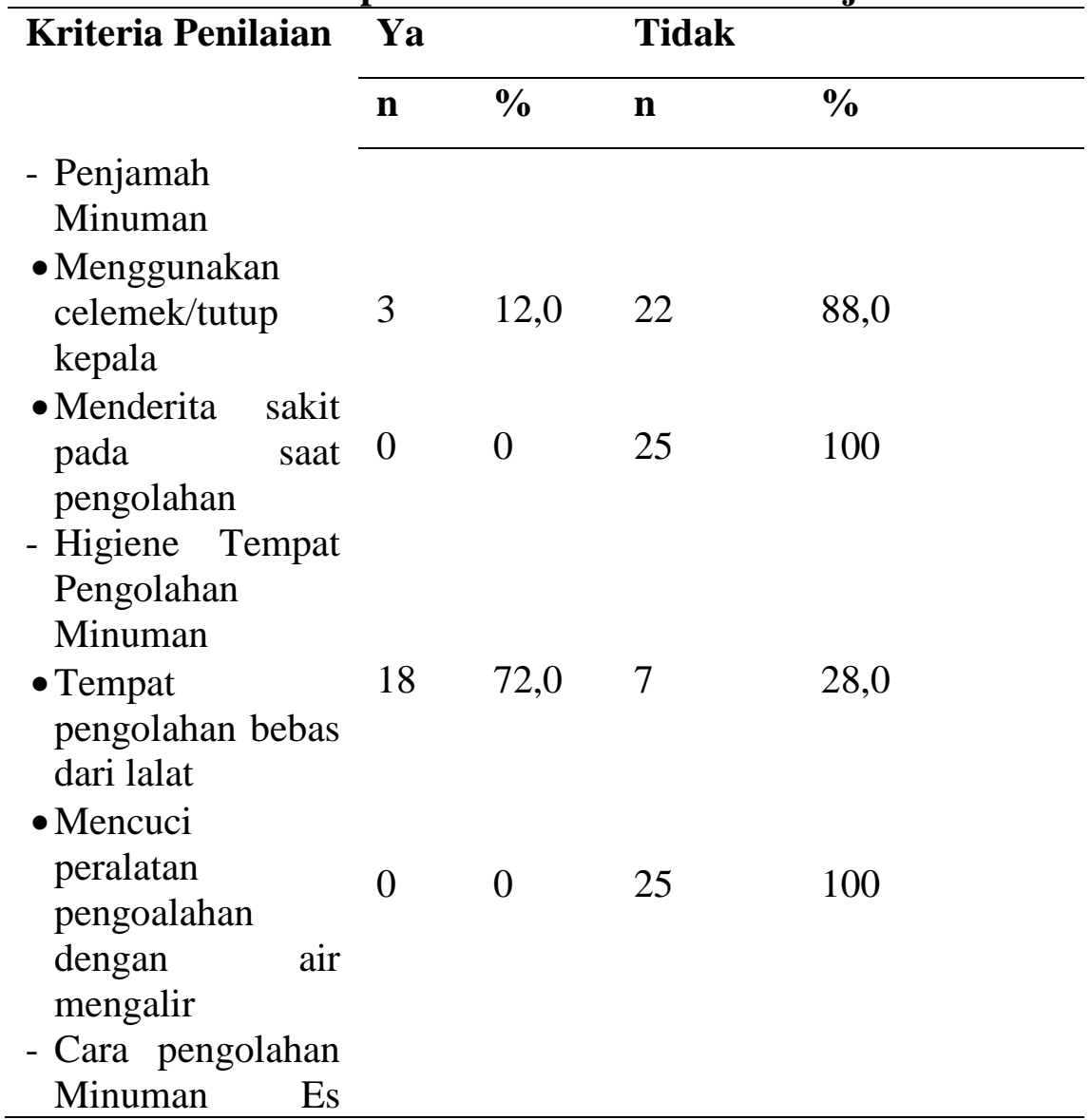




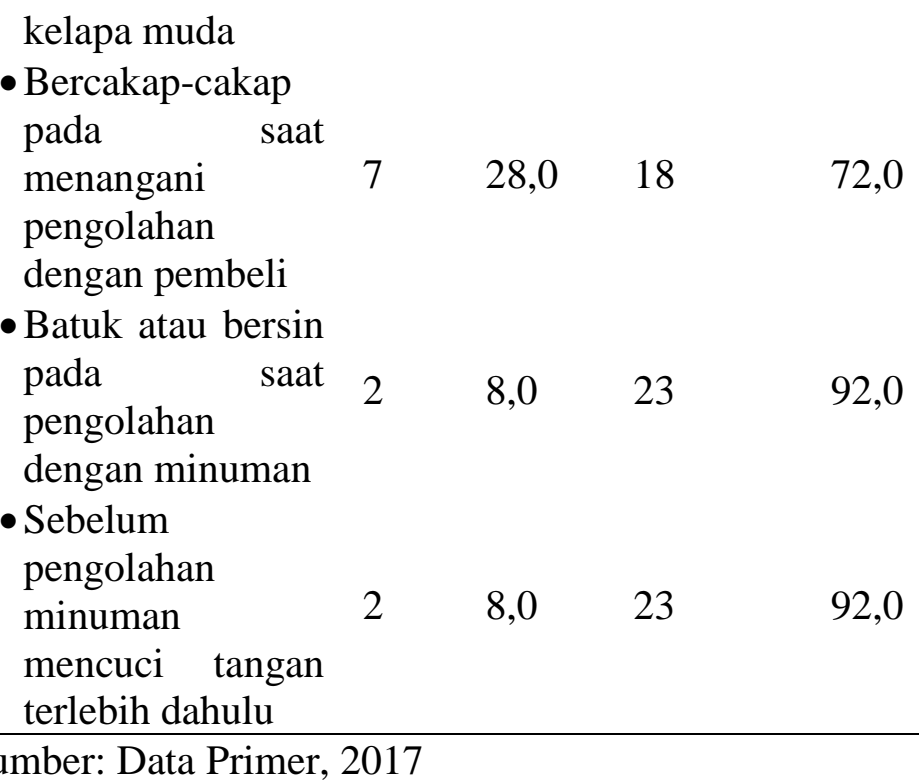

\section{Penyimpanan Minuman Es Kelapa Muda}

Tabel 6.

Distribusi Responden Berdasarkan Pemyimpanan Minuman Es Kelapa Muda Di Kecamatan Banjarbaru Utara

\begin{tabular}{lllll}
\hline Kriteria Penilaian & Ya & \multicolumn{3}{c}{ Tidak } \\
\cline { 2 - 5 } & $\mathbf{n}$ & $\mathbf{\%}$ & $\mathbf{n}$ & $\mathbf{\%}$ \\
\hline $\begin{array}{l}\text { Disimpan di dalam } \\
\text { termos atau wadah }\end{array}$ & 84,0 & 4 & 16,0 \\
yang bersih dan & & & \\
tertutup & & & \\
$\begin{array}{l}\text { Air kelapa muda } 20 \\
\text { disimpan didalam } \\
\text { termos dari pagi }\end{array}$ & 80,0 & 5 & 20,0 \\
sampai sore
\end{tabular}

Sumber : Data Primer, 2017

7. Pengangkutan Minuman Es Kelapa Muda

Tabel 7.

Distribusi Responden Berdasarkan Pengangkutan Minuman Es Kelapa Muda Di Kecamatan Banjarbaru Utara

\begin{tabular}{|c|c|c|c|c|}
\hline \multirow[t]{2}{*}{ Kriteria Penilaian } & \multicolumn{2}{|l|}{ Ya } & \multicolumn{2}{|c|}{ Tidak } \\
\hline & $\mathbf{n}$ & $\%$ & $\mathbf{n}$ & $\%$ \\
\hline $\begin{array}{ll}\text { Ada tempat } & \text { untuk } \\
\text { mengangkut } & \\
\text { minuman } & \text { yang } \\
\text { sudah jadi } & \end{array}$ & 0 & 0 & 25 & 100 \\
\hline $\begin{array}{l}\text { Minuman yang } \\
\text { diangkut dalam } \\
\text { keadaan tertutup }\end{array}$ & 0 & 0 & 25 & 100 \\
\hline
\end{tabular}

Sumber : Data Primer, 2017 


\section{Penyajian Minuman Es Kelapa Muda}

Tabel 8.

Distribusi Responden Berdasarkan Penyajian Minuman Es Kelapa Muda Di Kecamatan Banjarbaru Utara

\begin{tabular}{llllc}
\hline Kriteria Penilaian & \multicolumn{2}{c}{ Ya } & \multicolumn{1}{c}{ Tidak } \\
\cline { 2 - 5 } & $\mathbf{n}$ & $\mathbf{\%}$ & $\mathbf{n}$ & $\mathbf{\%}$ \\
\cline { 2 - 5 } & 24 & 96,0 & 1 & 4,0 \\
$\begin{array}{l}\text { Peralatan penyajian dalam } \\
\text { keadaan bersih }\end{array}$ & 1 & 4,0 & 24 & 96,0 \\
$\begin{array}{l}\text { Peralatan penyajian dicuci } \\
\text { dengan air mengalir }\end{array}$ & 22 & 88,0 & 3 & 12,0 \\
$\begin{array}{l}\text { Setelah dicuci peralatan } \\
\text { dikeringkan }\end{array}$ & 21 & 84,0 & 4 & 16,0 \\
$\begin{array}{l}\text { Peralatan penyajian bebas } \\
\text { dari lalat }\end{array}$ & 24 & 96,0 & 1 & 4,0 \\
\hline Penyaji berpakaian bersih & 24 &
\end{tabular}

Sumber: Data Primer, 2017

\section{Hasil Pemeriksaan Bakteri E.Coli}

Tabel 9.

Data Hasil Pemeriksaan Bakteri E.Coli pada Es Kelapa Muda di Kecamatan Banjarbaru Utara

\begin{tabular}{lccc}
\hline No & Sampel & $\begin{array}{c}\text { Total E. } \\
\text { Coli/100ml }\end{array}$ & Ket \\
\hline 1 & A & 67 & + \\
2 & B & 67 & + \\
3 & C & 67 & + \\
4 & D & 67 & + \\
5 & E & 67 & + \\
6 & F & 67 & + \\
7 & G & 67 & + \\
8 & H & 67 & + \\
9 & I & 67 & + \\
10 & J & 67 & + \\
11 & K & 979 & + \\
12 & L & 979 & + \\
13 & M & 0 & - \\
14 & N & 7 & + \\
15 & O & 979 & + \\
16 & P & 2 & + \\
17 & Q & 0 & - \\
18 & R & 4 & + \\
19 & S & 0 & + \\
20 & T & 7 & + \\
21 & U & 7 & + \\
22 & V & 4 & - \\
23 & W & 0 & + \\
24 & X & 979 & - \\
25 & Y & 0 & \\
\hline
\end{tabular}

Sumber : Data Laboraturium Kesehatan, 2017 